\title{
Deregulation and Open Capital Markets: The Australian Experience Before Wallis
}

\author{
Gordon de Brouwer
}

$\mathbf{M}$ UCH has been written recently on the 1998 'Wallis reforms' to the Australian financial system. But while they are important, they follow an earlier period of financial deregulation. Australia started liberalising its financial markets in the 1970s, and the process was essentially completed by 1986 .

This article reviews the reform sequence before Wallis, and examines the effects (some of which were unexpected) of reform on financial and other markets, the macroeconomy, and the policy environment. In particular, implications for the transmission of monetary policy are examined, along with soisic of the challenges that liberalisation and internationalisation pose for policy-makers.

\section{The Sequence of Financial Reforms}

This section outlines the sequence and motivation of reform up to, but not including, the Financial System ('Wallis') Inquiry (1997). 'At the start of the 1970s, the Australian financial system was closed and highly regulated. Interest rates were controlled by the authorities, strict limits were placed on bank lending, financial institutions were required to buy government securities at non-market prices, and movements of capital into and (especially) out of the country were tightly controlled. This system was reformed gradually between the mid-1970s and the mid-1980s. The domestic financial system and the capital account were reformed more or less simultaneously.

Domestic reform comprised the two elements of deregulating bank operations (notably the removal of controls over interest rates on certificates of deposits in September 1973, other bank deposits in December 1980, and loan rates in April 1985) and liberalising markets in government securities (notably the shift from a 'tap' to a market-based tender system for Treasury Notes in December 1979 and Treasury Bonds in August 1982). Deregulation of banking operations gave banks responsibility, allowing them to shift from simple credit allocation to liabilities management

A chronology of reform of the domestic financial sector and the capital account is provided in an Appendix. Accounts of financial deregulation in Australia include Harper (1986), Battellino and Macmillan (1989), Milbourne (1990), Carew (1991), Grenville (1991), Lowe (1994, 1995), Gruen (1994), Edey and Gray (1996) and Financial System Inquiry (1997).

Gordon de Brouwer is Chief Manager, International Markets and Relations, International Department at the Reserve Bank of Australia. 
in the face of market-determined demand for credit. The liberalisation of government securities substantially deepened financial markets for both domestic and foreign portfolio investors.

The key reform on the international side was the floating of the exchange rate and the removal of most capital controls in December 1983. The prior history of deregulation of the capital account was not one of uniform movement towards a deregulated system: in the 1970s, controls on capital inflows were intensified or moderated a number of times in response to the strength of those flows and the authorities' intention to control them. Liberalisation did not proceed along a straight path.

Some basic aspects of Australia's sequence of reform are of interest. First, as is clear from the development literature, countries which initiate major rapid reform usually do so because they face a crisis which leaves them little choice but to respond with big changes. In the case of Australia, reform was mostly gradual because policy, markets and institutions were relatively stable. The exception to this was floating the currency on 9 December 1983, which occurred in response to destabilising capital flows.

Second, although studies such as the Campbell Committee Report in 1981 and the Martin Report in 1983 were influential, reform was largely the result of policymakers being adaptive and making judgments about which institutional arrangements yield a better economic and social outcome. Reform was pragmatic rather than ideological. As institutions and markets developed, it became clear that better outcomes would be delivered by the market. At the end of the 1970s and early 1980 s, the view that free and open financial markets would improve the effectiveness of policy, the operation of firms and the well-being of households became more widespread, particularly among policy-makers.

Third, the move to liberalise markets became irresistible. On the domestic front, banks were subject to extensive controls, which induced disintermediation in the form of the establishment and spread of non-bank financial intermediaries, but which, for constitutional reasons, lay outside the control of the central bank. The monetary authorities were using an instrument (quantitative controls and interest rate regulations) over an ever-narrowing set of financial institutions. Deregulation and liberalisation gave the monetary authorities an instrument (the short-term interbank interest rate) which affected not only banks, but all financial intermediaries and the whole range of financial prices, from bank deposit and loan interest rates to bond yields and share prices.

Fourth, if the move to reform was inevitable, the process of reform itself set in train ineluctable pressures for further, continued reform. As controls were eased in one segment of the market, the pressure for reform in some other segment grew

\footnotetext{
2 The exchange controls that remain are not substantial, and include, for example, requirements that all foreign exchange transactions are intermediated by authorised foreign exchange dealers.

${ }^{3}$ See, for example, Gelb, Jefferson and Singh (1993), Haggard, Lee and Maxfield (1993) and Goldsborough et al. (1996).
} 
(Harper, 1986). For example, liberalisation of private money-market instruments and bank deposit rates left the government little choice but to sell its securities at market prices. Reform sets off snowball effects, and, given the progress in technology, these are probably even greater today.

Fifth, the domestic and international financial systems are inextricably linked, and it is difficult to separate reform of the domestic financial system from reform of the capital account. The development of market-priced domestic debt markets, for example, made it more difficult to isolate foreign portfolio investment. In a gradual reform sequence, domestic and international reform occur in tandem.

\section{Expected Benefits of Financial Reform}

In their study on the effects of financial liberalisation on OECD economies, Edey and Hviding (1995) argue that liberalisation has provided three general benefits. First, it has improved internal efficiency in banking firms, as shown by declining operating costs and some fall in interest margins. It has improved allocative efficiency by removing distortions in relative funding costs and providing greater opportunities for international portfolio diversification. Finally, it has reduced liquidity constraints and so enabled households to better smooth consumption over time.

From a broad overview, these three gains are evident for Australia. Competition in the banking sector, especially for commercial wholesale finance and, more recently, housing finance, has substantially increased. As a result, average margins in banking have declined moderately, as shown in Figure 1. Operating expenses have also fallen from about 4 per cent of assets in 1980 to around 3 per cent today. The decline in interest margins on personal loans, however, occurred only in 1996, as loan securitisation became more popular. Competition has had an effect, but it has been slower to take effect than expected.

Liberalisation has also increased allocative efficiency, in the sense that savers and investors have more choice. Figure 2 shows how the institutional structure of the financial system has changed with deregulation. The bank sector, which was declining under regulation, has expanded, particularly through the entry of new banks. New sectors, particularly those involved with long-term saving, have grown substantially, suggesting that risk diversification has improved.

Liberalisation has greatly affected the ability of firms and households to smooth investment and consumption. For example, there is strong evidence that households are now more able to maintain consumption when there are temporary changes in their current income (Debelle \& Preston, 1995; de Brouwer, 1996). Obtaining the benefits for consumption smoothing (and probably investment smoothing) seems to depend on having both a liberalised and an open financial system (de Brouwer, 1996). The effect of financial liberalisation on investment and consumption smoothing is evident in how the current account and composition of capital flows have altered over time. As shown in Figure 3, the current account

\footnotetext{
- One factor behind the expansion of the financial system is saving in the form of compulsory superannuation. This detracts from diversification to the extent that it crowds out voluntary saving.
} 
deficit increased in the early 1980s, and the nature of capital flows shifted markedly from direct investment to more 'general purpose' portfolio investment.

Figure 1: Average interest margins, 1980-97

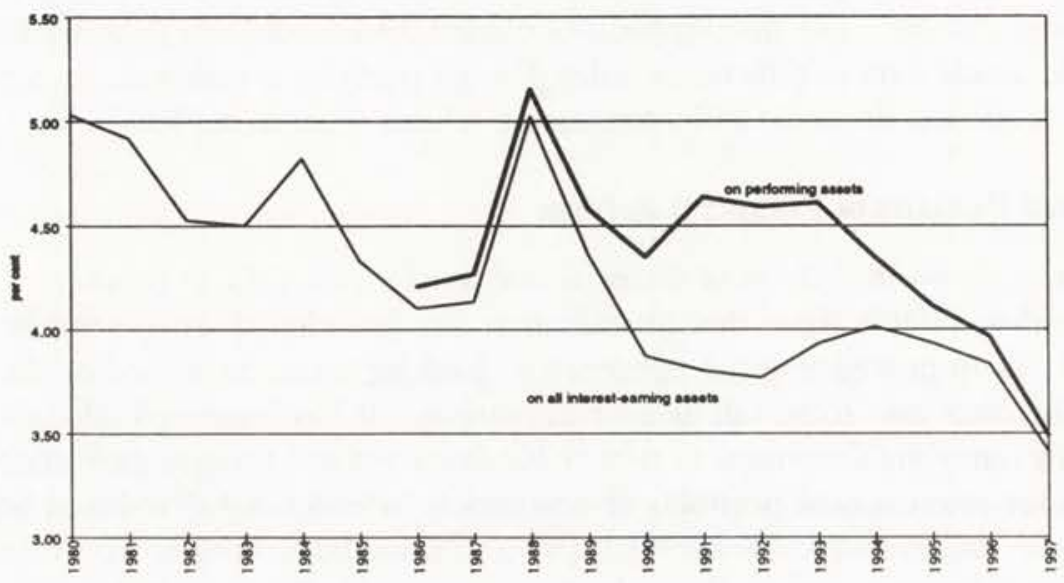

Source: Reserve Bank of Australia Bulletin.

Figure 2: Structure of the financial system, 1959-96

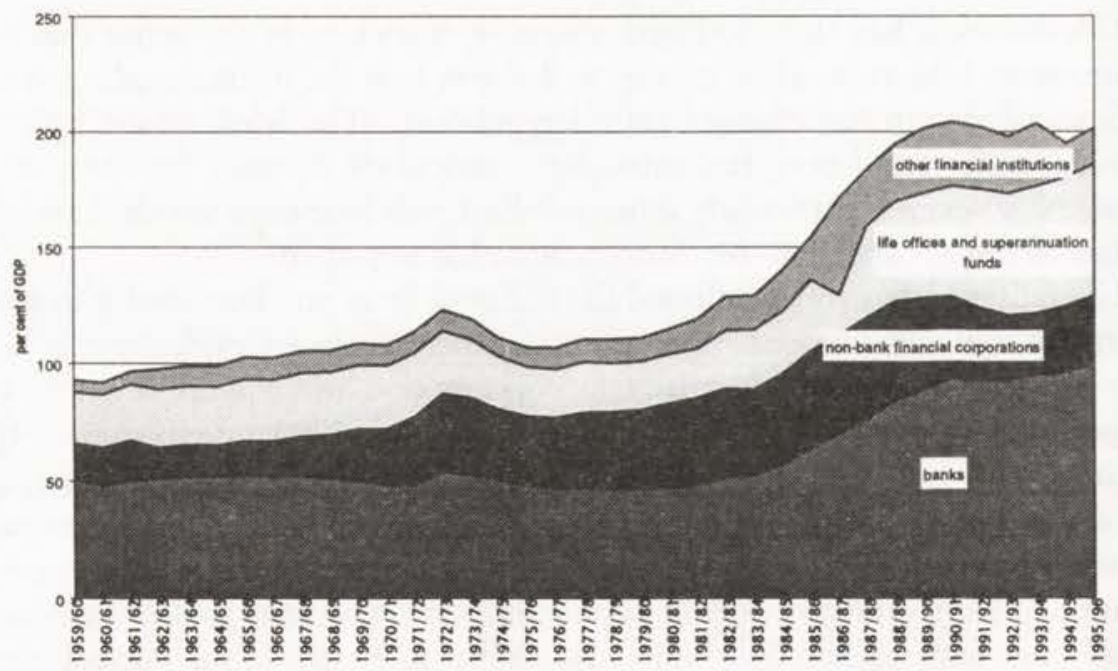

Source: Reserve Bank of Australia Bulletin. 
Figure 3: Current account and capital inflows, 1959-96

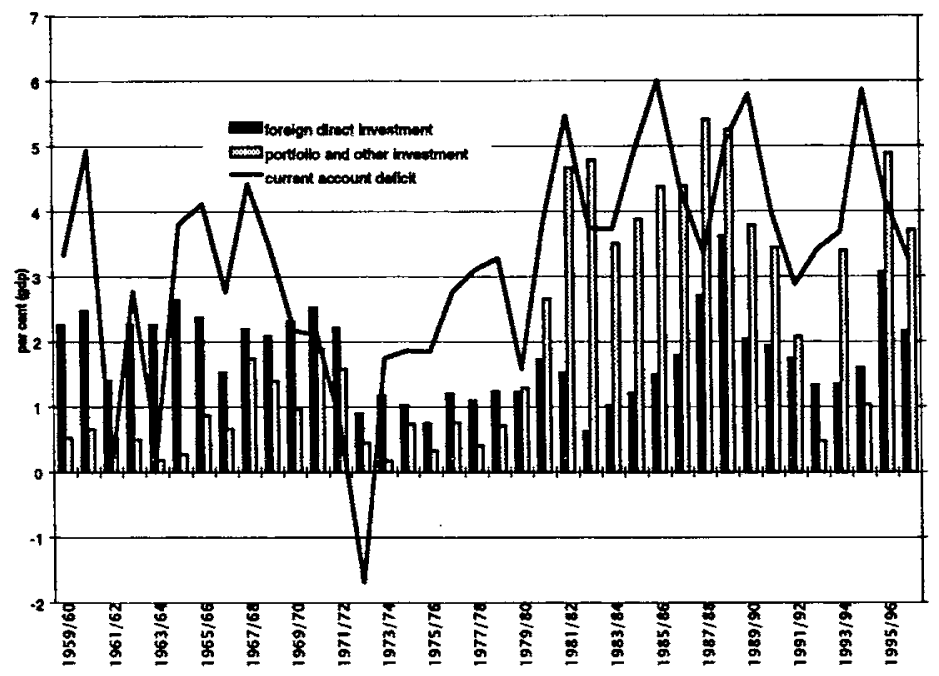

Source: Australian Bureau of Statistics.

\section{Operating Efficiency}

The triad of deregulation, liberalisation and internationalisation has had a range of effects on the operation of monetary policy. Reform has enhanced the operating efficiency of monetary policy in a number of ways.

First, in a regulated system, direct controls are applied to the balance sheets of one group of financial institutions, namely, banks. Disintermediation - the expansion of non-bank financial intermediaries and the contraction of banks - occurred as a result of these controls, forcing the burden of policy on an ever-smaller part of the financial system, and making monetary policy less effective. Deregulation, liberalisation and the shift to interest rate-based intervention changed this dramatically: not only were all financial institutions affected by policy changes, but the effect was transmitted to the full set of financial prices, including bond yields and share prices.

Moreover, the shift from a 'tap' system for the sale of Commonwealth government securities (CGS), whereby the government would set the interest rate and the market the quantity, to a tender system also gave the central bank greater control over monetary policy. This enhanced the marketability of CGS at a time of growing budget deficits, enabling the government to fund its deficit by borrowing from the public and not the central bank. Moreover, since interest rates on CGS tended to be insensitive to movements in market rates, these securities became even less marketable, and the reliance on central bank financing even greater, when monetary policy was tightened. This undermined a tightening of monetary policy. Hence, the shift in auction methods not only secured the independence of monetary policy 
from fiscal policy, but also boosted its efficiency.

Finally, floating the exchange rate in December 1983 also improved the control of the Reserve Bank of Australia (RBA) over domestic liquidity. As shown in Figure 4, after the war, Australia fixed its currency to British Sterling and, after decimalisation in 1966, to the US dollar until 1976. From November 1976 to December 1983, the exchange rate was determined under an adjustable peg system, by which the authorities set the exchange rate each morning and stood ready to clear any imbalances in the foreign exchange market at the end of the day. At times, these imbalances were large and unpredictable, severely undermining management of liquidity. This was remedied by floating the exchange rate.

Figure 4: Australian dollar, 1946-98

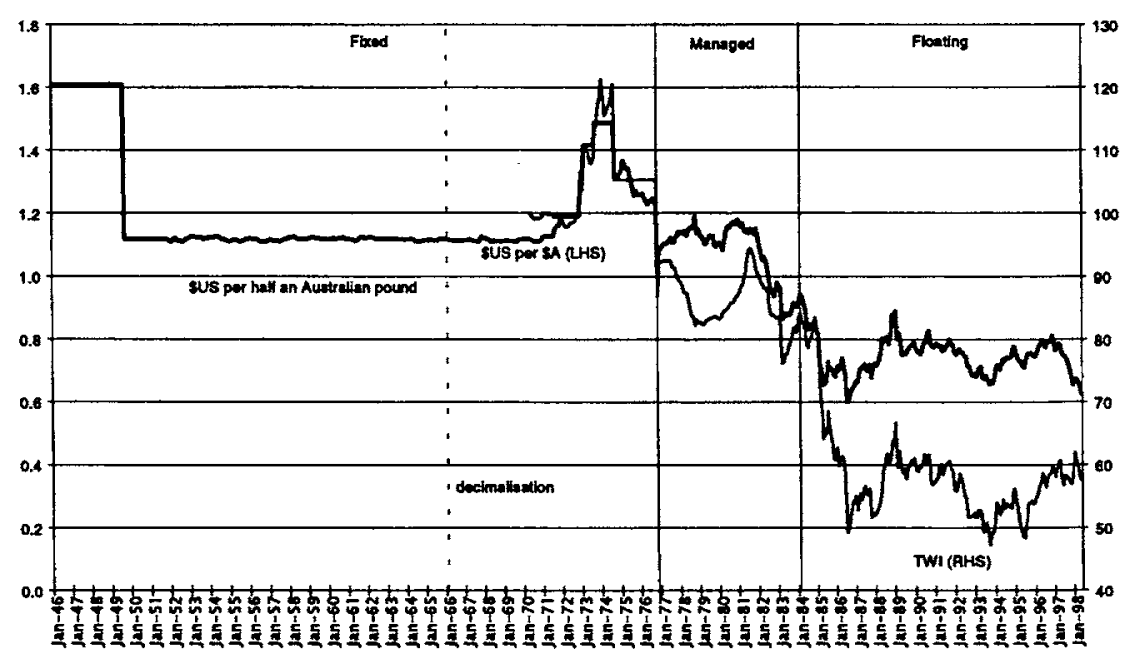

Source: Reserve Bank of Australia Bulletin.

\section{Effectiveness}

Reform has also enhanced the economic effectiveness of monetary policy.

The Mundell-Fleming framework indicates that, so long as the exchange rate is flexible, a country can pursue an independent monetary policy. In a deregulated economy, monetary policy operates by setting the short-term interest rate. Since prices are sticky, changes in the nominal rate imply changes in the real interest rate, which is also the interest rate that most affects economic activity (Gruen, 1994:58-9). This is the case for Australia. Figure 5 shows that Australian short real interest rates

\footnotetext{
${ }^{5}$ While the principle that Treasury Bonds would not be sold to the central bank for financing purposes was accepted, the central bank still purchased Treasury Notes until 1986. In August of that year, the Treasury and the Reserve Bank of Australia (RBA) exchanged letters agreeing that the central bank would no longer provide short-term funding for the government. This meant that the principle of full funding was adopted. See RBA (1993) for a detailed account.
} 
have deviated from real rates in the G3 economies, at least for periods long enough to matter to policy. Moreover, the real interest rate clearly affects economic activity, as shown in Figure 6.

Figure 5: Short-term real interest rates, 1980-97

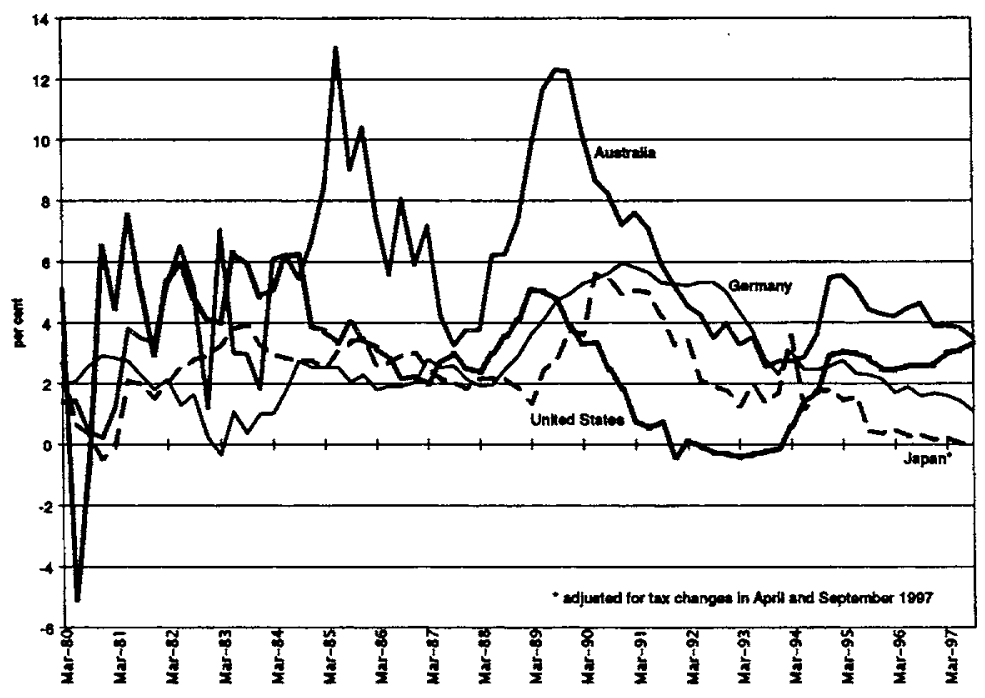

Source: Reserve Bank of Australia Bulletin.

Figure 6: Economic growth and the real interest rate, 1980-97

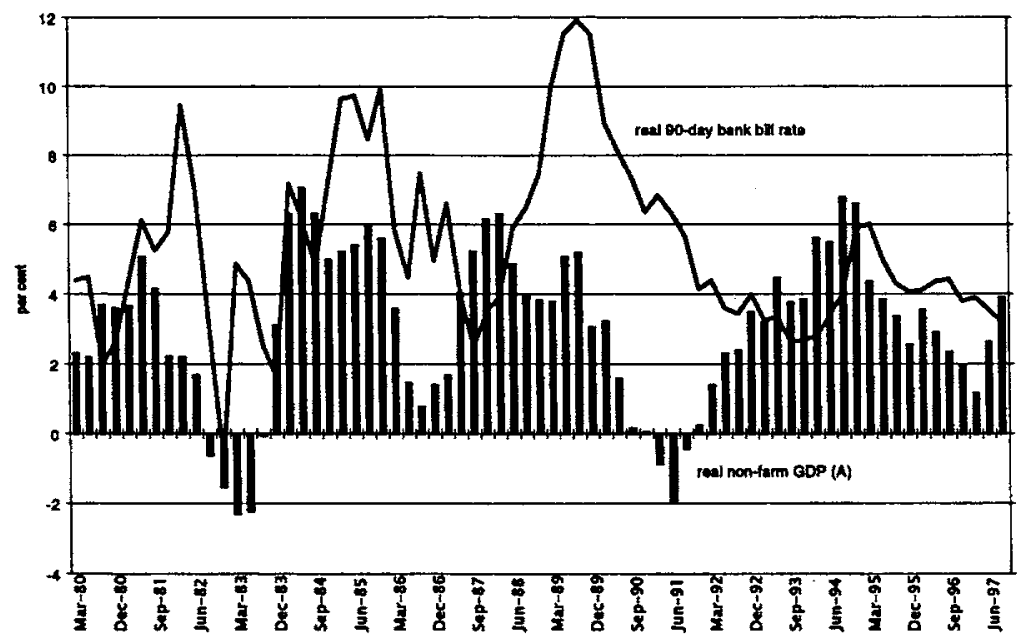

Sources: Reserve Bank of Australia Bulletin; Australian Bureau of Statistics. 
Reform has also opened up new and important channels by which changes in interest rates affect inflation and economic activity. There are at least five channels by which changes in interest rates affect the economy: inter-temporal substitution (the current cost of investment and consumption is affected, altering the decision whether to invest and consume now or later); cash flow (higher interest rates reduce cash flow and current spending); credit supply (higher interest rates change the mix of borrowers seeking loans, making banks more reluctant to lend); other asset effects (changes in short-term rates may affect bond yiclds and share prices); and the exchange rate (higher rates appreciate the exchange rate, lowering import price inflation, reducing foreign demand for domestic output and shifting domestic demand to foreign output) (Grenville, 1995). Liberalisation was instrumental in opening up these channels. When credit was rationed and interest rates fixed, quantitative controls, and not interest rates, were the fulcrum of monetary policy. In liberalised and open markets, financial prices, and the exchange rate in particular, play a key role in the transmission of monetary policy.

Moreover, the speed with which changes in policy affect output and inflation may be expected to be faster with financial liberalisation. For example, the speed with which changes in money market interest rates are transmitted to bankintermediated deposit and loan rates - and hence affect consumption and investment - depends on the degree of regulation and competition in the banking system (Lowe, 1995; de Brouwer, 1995). As banking has been deregulated and as competition has increased, the speed of transmission of policy may have increased. Similarly, as the exchange rate became more flexible and instrumental as part of the transmission mechanism, it also probably increased the speed with which changes in monetary policy affected output and inflation. The same probably holds true for other financial prices, like bond yields and share prices, which move rapidly when new information arrives. Changes in interest rates, however, do not seem to have affected output more quickly in the 1990s than in the 1980s (Gruen, Romalis \& Chandra, 1997).

Finally, financial reform, particularly floating the exchange rate, has significantly enhanced stabilisation policy and the automatic stabilisers in the economy. This has occurred in three ways. First, given the resource orientation of exports, Australia's terms of trade are among the most variable of the developed economies. Under a fixed exchange rate, a fall in export prices reduces domestic income directly and indirectly through the contraction of liquidity generated as capital inflows ease on the back of lower expected returns and export receipts. Income unambiguously falls. But if the exchange rate is flexible, the currency depreciates in response to a fall in the terms of trade, and this cushions the negative effect of the terms of trade fall on the traded goods sector. Output is stabilised. Moreover, the inflationary impact of the terms of trade also changes. Under fixed exchange rates, for example, a fall in the terms of trade is disinflationary, since income is lost and lower capital inflow reduces liquidity. But when the exchange rate is flexible, the income loss is smaller (and could even be a gain if the exchange rate depreciates enough) and the depreciation itself boosts consumer prices since import prices rise in domestic cur- 
rency terms. A fall in the terms of trade may even be inflationary (Dwyer \& Gruen, 1995).

Second, changes in the real exchange rate are effected by changes in the nominal exchange rate or in inflation. When the exchange rate is fixed, the inflation rate changes to generate the required real exchange rate adjustment, although adjustment is slower in this case than a change in the nominal rate since asset prices are much less sticky or persistent than goods and services prices. There is a strong preference for flexibility in the nominal exchange rate because, first, the output costs of achieving a real depreciation can be minimised and, second, high and variable inflation itself is costly.

Third, opening the economy tends to increase competition in goods and services markets, because it usually allows new entrants, and tends to make more markets 'traded' as opposed to non-traded. As a consequence, the market power of firms and labour to charge higher prices (in economists' jargon, to extract monopoly rents) falls. For example, as foreign competition becomes more important, domestic firms are forced to take account of the prices of their new competitors. Similarly, if workers set their wage claims too high, profits and sales fall for the firms that employ them, and they lose their jobs. Competition acts as a 'discipline' on both firms and workers. This also implies that the nature of 'shocks' may change. The economy, for example, may face fewer 'wages shocks', since wage increases which are not supported by an increase in productivity are likely only to end in more unemployment. Moreover, shocks are more likely to be transitory and just pass through the system if wages are not fully indexed. (One implication of this is that the outcomes associated with a particular monetary policy setting also depend on the institutional structure of the economy.)

\section{Challenges}

But reform has also opened up new challenges to policy.

In the first place, the size of, and turnover in, financial markets have expanded substantially, and the prices of financial instruments are affected by the policy interest rate. Exactly how other financial prices respond depends on the various markets' assessment of policy. Changes at the short end of the yield curve can quickly spread to the whole of the yield curve and to related financial returns, like share prices, and hence influence economic activity more rapidly. In this respect, the credibility of the central bank with respect to inflation is crucial. For example, an easing of short-term rates may reduce bond yields if the market considers the central bank to be credible and interprets the action as indicating that inflation is under control. If the central bank's credibility is low, however, bond yields may rise because the market thinks the central bank has 'lost the plot'. Markets impose a substantial discipline, not just on monetary policy, but also on fiscal, wages and competition policy.

In this respect, it is worth noting that, at least for Australia, a floating exchange rate is anything but a 'soft option'. Some commentators argue that fixing the currency to that of a low-inflation country is the best way to secure low inflation: float- 
ing gives policy-makers monetary independence, but it also means that they have the option of choosing higher inflation. This is not the case for Australia, since the markets are a discipline on inflationary policy. As it turns out, Australia's inflation performance after the float is superior to that of before the float: in the ten years before the float in December 1983, annual inflation averaged about 11 per cent, but since then it has averaged 5 per cent (and 2.5 per since 1991).

Second, the expectation that financial reform would give the central bank greater control over the monetary aggregates has not been borne out. Reform and technological change led to major changes in asset demand, rendering the monetary aggregates unstable and targets unattainable. Experimentation with a 'checklist' of indicators also proved unsatisfactory. In the end, left without an intermediate target, the RBA formulated monetary policy with direct reference to the ultimate policy objectives with respect to inflation and activity. This was clarified by the adoption of an inflation target, formally endorsed by the government, of keeping underlying inflation between 2 per cent and 3 per cent on average over the cycle. Since it takes between one and two years for a change in policy to have its full effect on employment and inflation, policy has to be forward-looking.

Third, as a number of OECD countries, including Australia, experienced in the late 1980s and early 1990s, the adjustment to financial deregulation was associated with asset price bubbles and a deterioration in the quality of bank assets. In Australia's case, easier access to funds, and intense competition between the banks for new business, generated an expansion of credit for investment, particularly in commercial property. This was amplified by rising asset values which boosted collateral and stimulated further expansion of bank loans and corporate balance sheets. Credit standards, on the whole, were loosened. When the economy slowed down and the bubble burst, non-performing loans severely eroded the profitability of the banking system, and left many firms over-leveraged. The recovery was delayed because institutions had to repair their balance sheets (Lowe, 1994; Mills, Morling \& Tease, 1994). There are two implications for policy. First, the excesses of the late 1980s were part of a learning process by commercial bankers, firms and bank supervisors, and are not intrinsic to deregulation itself (Lowe, 1994; RBA, 1996:52). (Whether other countries have gained this insight vicariously, however, is an open question.) Second, proper credit and market risk systems need to be in place when finance is liberalised. Crucial elements of this are that commercial bank officers have sufficient expertise to assess, monitor and control risk; that banks have adequate contingency reserves; and that bank auditors and supervisors ensure that minimum standards are clear and effective systems in place and enforced. Advances along this line in Australia include the introduction of on-site bank examinations and the focus on managing market risk, rather than just credit risk. The Financial System Inquiry (1997) also recommended strengthening the surveillance of financial intermediaries by combining existing supervisory institutions into one.

The fourth broad challenge is to understand financial markets. This centres on two related issues. The first is that financial prices and capital flows sometimes seem to be excessively volatile, making policy formation difficult. The second is 
that market reactions sometimes seem 'excessive'. It has been well documented, for example, that financial markets can be too focused on the short term, too sensitive to new information, or too caught up in fads that drive financial prices away from the economic fundamentals which are thought to lie behind them. This may be, in part, because they sometimes follow risk-management techniques or trading rules - like charting, technical analysis, program trading, stop-loss orders and dynamic hedging techniques - that are not necessarily related to macroeconomic fundamentals (Argy, 1996).

Consider, first, volatility in financial prices, and the exchange rate in particular. While volatility in OECD currencies has been greater after the collapse of the Bretton Woods system of fixed exchange rates in 1971, Edey and Hviding (1995) point out that trend volatility has not increased in this period, even if there are particular episodes of substantial volatility. Gruen (1994) shows that volatility in Australia has been similar to that in other countries. On the economic effects of volatility, however, the literature is mixed, and the issue remains open. But in relation to Australia, a first glance at the data suggests that variability in output has not increased over the past few decades (Gruen, 1994), although this observation does not take account of the effect of other shocks, like oil price rises, that occurred in earlier decades.

Volatility in capital flows is something that policy-makers have grappled with for decades. In the 1970s, capital controls were applied and removed a number of times in response to the strength of capital inflows. The need to use controls depended largely on how fixed the exchange rate was. As the currency became more flexible, notably in the shift from a fixed to pegged (or semi-fixed) rate in 1976, the need to impose controls fell. The pegged rate system, however, still provided speculators with a one-way bet against the central bank - and ultimately taxpayers - and itself induced highly destabilising capital flows. For example, as indicated in Figure 7, in February 1983 the market expected a devaluation of the Australian dollar, sold the currency and bought foreign exchange, leading to a fall in reserves and inducing a devaluation. In December of that year, the market expected a revaluation and started to buy Australian dollars. The government floated the dollar, forcing speculators to speculate against themselves. In the process, the authorities gained control over liquidity.

As discussed above, a flexible exchange rate provides clear benefits to a small open economy like Australia. Moreover, a country with substantial resource endowments but small population and limited domestic capital like Australia will also be highly dependent on foreign capital. The best way to ensure stability in capital

\footnotetext{
6 For example, Gruen and Kortian (1996) provide evidence that the foreign exchange market incorporates near-term expected changes in the terms of trade into the Australian dollar, but not medium- and long-term changes. Isard (1995) concludes that covered interest parity is less likely to hold on longdated instruments than on short-dated ones. Davidson, Okunev and Tippett (1996) present evidence that the US and UK stock markets overdiscount longer-term corporate earnings, arguing that this may be due to excessive focus on the short term. Cutler, Poterba and Summers $(1990 \mathrm{a}$, b) find significant short-term positive autocorrelation in excess returns on a range of financial assets, which they interpret as evidence of feedback trading, such as charting, and short-term inefficiencies.
} 
flows is to run stable and long-term sustainable economic policies. Policies that support low inflation, fiscal sustainability, a stable financial system, education and the rule of law seem to be crucial to this (Sachs, Tornell \& Velasco, 1996; Barro, 1996).

\section{Figure 7: Capital inflows and floating the Australian dollar}

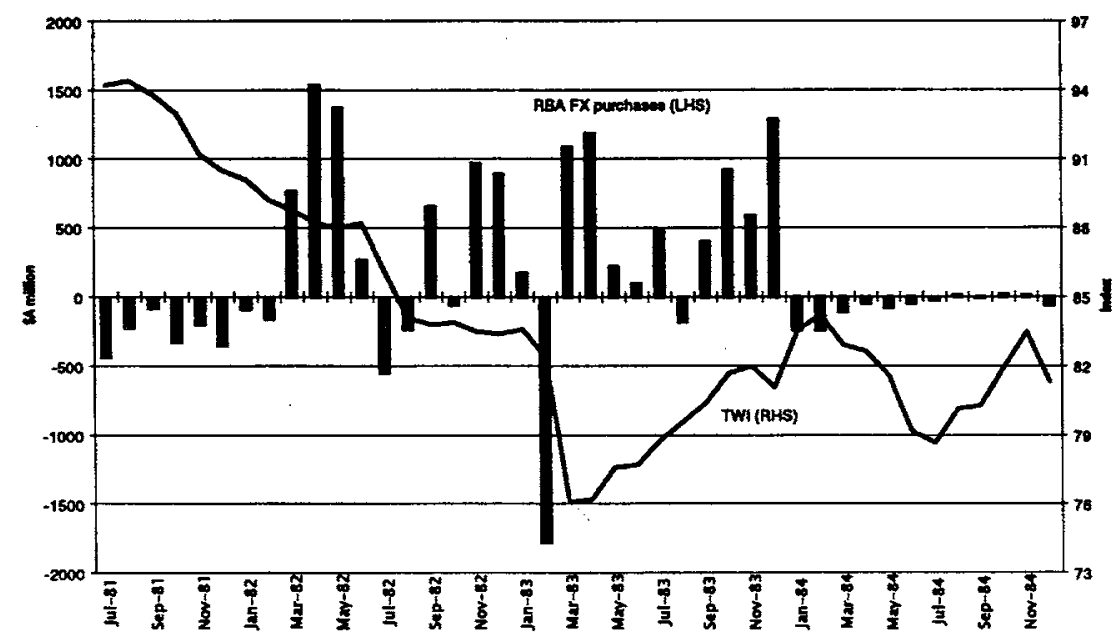

Source: Reserve Bank of Australia Bulletin.

A further issue is the difficult question of whether financial prices reflect fundamentals. This involves, first, a judgment about what fundamentals are. Take the real exchange rate, for example. The fundamental determinants of the Australian real exchange rate are commonly regarded as being the terms of trade, real interest differentials, net foreign liabilities and, perhaps, fiscal policy (Blundell-Wignall et al., 1994; Tardit, 1996). Given relationships based on past average responses, it is possible to form some view of the 'fundamental' value of the currency. These judgments are not precise, since they are based on estimates and the effect on the fundamental value depends on the permanence of the shock. Central banks also form a view on whether movements in bond prices and yields reflect changes in fundamentals, such as expected inflation or the global demand for and supply of capital, or are due to 'market dynamics'.

But the issue is more complicated. An event described as market-driven may, in fact, be a failure of policy itself; the market may simply have been doing its job. Or there may be elements of both forces: a fundamental need for policy adjust-

\footnotetext{
${ }^{7}$ While elaborately transformed manufactures now account for about a quarter of Australia's exports, resources have been the mainstay of Australia's export base. Resource prices, however, are relatively volatile, and this generates more variability in the terms of trade than for most developed economies. This is reflected in the real exchange rate.
} 
ment exacerbated by market over-reaction to the situation. The 1992 European and the 1994 Mexican exchange rate crises may be examples. German reunification, for example, was tantamount to a major negative supply shock and positive demand shock for Germany. The only way to contain incipient inflation and the sharp increase in demand for capital was to raise local interest rates and allow a real revaluation of the German mark. But nominal revaluation was not possible within the framework of fixed exchange rates in the European Monetary System, and so all countries in the system were bound to undergo rising interest rates at a time when demand in their economies was weak. For some countries, like the United Kingdom, Italy and Spain, this was not a credible policy given their domestic circumstances, and markets reacted accordingly. The Mexican crisis of 1994 occurred against a backdrop of rapid accumulation of short-term US dollar-denominated liabilities, without a build-up of foreign exchange reserves, but with a marked deterioration in Mexico's fiscal position and increased political uncertainty (IMF, 1995:907). Again, markets were reacting to a situation they saw as unsustainable. The story of East Asia in 1997 is likely to have similar elements.

More difficult, however, is what to do if there is a market misalignment or clear over-reaction. If a market correction is imminent, or the misalignment small, then no special response may be required. But if the misalignment is judged to be large and persistent, or market reaction to some event excessive, then some policy response may be appropriate. A number of responses to these sorts of events are possible:

- persuasion. through speeches and written assessments of the economy and financial markets. A central bank might indicate at times that it regards the reaction in particular financial markets to have been excessive;

- sterilised intervention in the foreign exchange market to signal that the central bank judges that market's response to be excessive. While sterilised intervention does not change the liquidity in the system (it merely changes the composition of central bank assets), it can influence the market's expectations and provide stability to the exchange rate in periods of uncertainty. In Australia, intervention was significantly used in the second half of the 1980 s when the market was fairly unsettled, particularly following the 'banana republic' comment by the then Treasurer in mid-1986, and the strong appreciation of the Australian dollar in February 1989 (when the Australian dollar reached US\$0.90) (Campbell, 1995); and

- use of short-term interest rates to influence capital flows. This is a feature of monetary policy decision-making in a number of countries where the exchange rate is an important focus of policy. In Australia, monetary policy is primarily focused on internal objectives. An example of the use of interest rates to influence capital flows was in mid-1986, when short-term interest rates were increased to resist the depreciation of the exchange rate (Lowe, 1994:167-8). 


\section{Conclusion}

Financial deregulation, liberalisation and internationalisation have had pervasive effects on the economy. This triad of reform has brought many beneits, particularly in terms of financial market efficiency and macroeconomic stabilisation. For example, interest margins have narrowed, portfolios have expanded, and firms and households have found it easier to 'smooth' their spending. Moreover, the floating exchange rate has reduced the impact of real external shocks on output and inflation. But reform has also raised some new challenges for policy-makers, including greater discipline on monetary and fiscal policies and the need to keep watch on stability in financial markets and in the banking system.

\section{Appendix}

\section{Chronology of Financial Reform in Australia}

At the start of 1970, in regard to the domestic financial market, quantitative controls were applied to bank lending, general controls on the products banks could offer, and interest rate controls on both deposits and loans. Banks were licensed either as trading banks or as savings banks. In 1968, banks were allowed to offer lease financing beyond overdraft limits, and in 1969 trading banks were allowed to issue certificates of deposit and savings banks allowed to offer investment accounts (both subject to prescriptions).

In regard to the capital account, all international transactions were subject to exchange control approval by the RBA. The only laws affecting foreign investment in Australia were in the areas of banking, civil aviation, radio and television. The most acceptable forms of investment were those which contributed to development, introduced new technology or products, established new operations, or included some local equity or management. Investment judged to be speculative or subverting local control was discouraged. Australian investment abroad was virtually embargoed, with approval granted only in exceptional circumstances. Direct investment abroad was allowed if it promoted export markets or served to protect or expand an existing interest. 


\section{Major financial reforms in Australia, 1970-96}

\begin{tabular}{|c|c|c|}
\hline Date & Domestic financial reform & Capital account reform \\
\hline Mar 70 & $\begin{array}{l}\text { Savings bank deposit rates allowed to be } \\
\text { varied subject to the maximum rate set } \\
\text { by the RBA. }\end{array}$ & \\
\hline Oct 70 & $\begin{array}{l}\text { Savings bank prescribed asset ratio } \\
\text { (forcing purchase of govermment } \\
\text { securities) reduced from } 65 \text { to } 60 \text { per } \\
\text { cent. }\end{array}$ & \\
\hline Aug 71 & $\begin{array}{l}\text { Minimum balance on savings banks } \\
\text { investment accounts reduced from } \$ 500 \\
\text { to } \$ 100 \text {, and the minimum transaction } \\
\text { requirement dropped. }\end{array}$ & \\
\hline Sept 71 & & $\begin{array}{l}\text { RBA introduces surveillance of capital } \\
\text { transactions bringing more than A } \$ 250,000 \\
\text { into Australia. }\end{array}$ \\
\hline Feb 72 & $\begin{array}{l}\text { Maximum interest rate on overdrafts, } \\
\text { housing loans and trading bank } \\
\text { deposits over A } \$ 50,000 \text { removed. }\end{array}$ & \\
\hline Sept 72 & & $\begin{array}{l}\text { Embargo on foreign borrowings with a ma- } \\
\text { turity of two years or less; guidelines on } \\
\text { overseas companies borrowing in Australia } \\
\text { (introduced May 1965) removed. }\end{array}$ \\
\hline $\operatorname{Dec} 72$ & & $\begin{array}{l}\text { Variable deposit requirement (VDR) } \\
\text { scheme introduced, by which } 25 \text { per cent of } \\
\text { funds borrowed from overseas were lodged } \\
\text { with the RBA in a non-interest bearing ac- } \\
\text { count until the borrowing was repaid. }\end{array}$ \\
\hline $\operatorname{Mar} 73$ & & $\begin{array}{l}\text { Restrictions placed on foreign real estate } \\
\text { investment in Australia, unless the pur- } \\
\text { chase was incidental to another purpose. }\end{array}$ \\
\hline Sept 73 & $\begin{array}{l}\text { Interest rate ceilings on certificates of } \\
\text { deposit removed, and the maximum term } \\
\text { extended from } 2 \text { to } 4 \text { years. }\end{array}$ & \\
\hline Oct 73 & & VDA raised from 25 to 33.3 per cent. \\
\hline June 74 & & VDR reduced to 5 per cent. \\
\hline Sept 74 & $\begin{array}{l}\text { Savings banks prescribed asset ratio } \\
\text { reduced from } 60 \text { to } 50 \text { per cent. }\end{array}$ & \\
\hline Nov 74 & & $\begin{array}{l}\text { VDR abolished; embargo on foreign bor- } \\
\text { rowings (September 1972) eased to apply } \\
\text { only to loans of less than six months. }\end{array}$ \\
\hline $\operatorname{Jan} 75$ & $\begin{array}{l}\text { Banks' agreement to maintain uniform } \\
\text { fee structure discontinued since it was } \\
\text { contrary to Trade Practices Act. }\end{array}$ & \\
\hline $\operatorname{Jan} 76$ & & $\begin{array}{l}\text { Foreign Takeovers Act } 1975 \text { comes into } \\
\text { force, giving the government authority to } \\
\text { prohibit a foreign takeover if it is deemed } \\
\text { contrary to the 'national interest'. }\end{array}$ \\
\hline Feb 76 & Limit extended to $A \$ 100,000$. & \\
\hline April 76 & & $\begin{array}{l}\text { Foreign Investment Review Board estab- } \\
\text { lished. }\end{array}$ \\
\hline $\operatorname{Jan} 77$ & & $\begin{array}{l}\text { Embargo on foreign borrowings re-extended } \\
\text { to two years or less; VDR revived and set at } \\
25 \text { per cent. }\end{array}$ \\
\hline May 77 & $\begin{array}{l}\text { Prescribed asset ratio reduced from } 50 \\
\text { to } 45 \text { per cent. }\end{array}$ & \\
\hline July 77 & & $\begin{array}{l}\text { Embargo on foreign borrowings relaxed to } \\
\text { apply only to borrowings of six months or } \\
\text { less; VDR suspended. }\end{array}$ \\
\hline
\end{tabular}


June 78

General relaxation in foreign Investment policy, including suspending the embargo on overseas borrowings of six months or less.

\begin{tabular}{|c|c|c|}
\hline Aug 78 & $\begin{array}{l}\text { Prescribed asset ratio reduced from } 45 \\
\text { to } 40 \text { per cent. }\end{array}$ & \\
\hline July 80 & & $\begin{array}{l}\text { Surveillance of capital inflows to Australia } \\
\text { eased. }\end{array}$ \\
\hline Dec 80 & $\begin{array}{l}\text { Interest rate ceilings on all bank deposits } \\
\text { removed. }\end{array}$ & \\
\hline July 81 & & $\begin{array}{l}\text { All restrictions on Australian investment } \\
\text { overseas in equities and real estate re- } \\
\text { moved (although foreign exchange approval } \\
\text { from the RBA was still required). }\end{array}$ \\
\hline June 82 & $\begin{array}{l}\text { RBA ceases quantitative lending guid- } \\
\text { ance. }\end{array}$ & \\
\hline Aug 82 & $\begin{array}{l}\text { Prescribed asset ratio replaced by a } \\
\text { much lower reserves asset ratio. }\end{array}$ & \\
\hline May 83 & & $\begin{array}{l}\text { Interest paid to non-residents by Austra- } \\
\text { lians subject to a withholding tax. }\end{array}$ \\
\hline Dec 83 & & $\begin{array}{l}\text { Australian dollar floated and most exchange } \\
\text { controls abolished. }\end{array}$ \\
\hline Aug 84 & $\begin{array}{l}\text { All remaining controls on the terms and } \\
\text { conditions of bank deposits removed; } \\
\text { savings banks allowed to offer cheque- } \\
\text { ing facilities. }\end{array}$ & \\
\hline $\tan 85$ & & $\begin{array}{l}\text { Some restrictions relating to foreign in- } \\
\text { vestment in Australian securities lifted, } \\
\text { allowing foreign government agencies and } \\
\text { foreign banks, other than central banks, to } \\
\text { invest in Australian securities. }\end{array}$ \\
\hline Feb 85 & & Entry of 16 foreign banks \\
\hline April 85 & $\begin{array}{l}\text { Remaining ceilings on interest rates } \\
\text { removed, except for owner-occupied } \\
\text { housing loans under } A \$ 100,000 \text {. }\end{array}$ & \\
\hline Sept 85 & & $\begin{array}{l}\text { Establishment of } 45 \text { new merchant banks, } \\
\text { and } 19 \text { proposals for restructuring of exist- } \\
\text { ing merchant banks, approved. }\end{array}$ \\
\hline Oct 85 & & $\begin{array}{l}\text { Significant relaxation in existing procedures } \\
\text { for screening foreign investment proposals. }\end{array}$ \\
\hline April 86 & $\begin{array}{l}\text { Interest rate ceiling on new owner- } \\
\text { occupied housing loans removed, exist- } \\
\text { ing loans still subject to maximum rate of } \\
13.5 \text { per cent. }\end{array}$ & \\
\hline July 86 & & $\begin{array}{l}\text { Removal of exemptions from interest with- } \\
\text { holding tax on Australian securities, but } \\
\text { policy reversed; foreign investment in } \\
\text { manufacturing and real estate guidelines } \\
\text { relaxed. }\end{array}$ \\
\hline April 87 & & Foreign takeover guidelines relaxed. \\
\hline Sept 88 & $\begin{array}{l}\text { Reserves asset ratio replaced by prime } \\
\text { asset ratio, by which } 10 \text { per cent of li- } \\
\text { abilities (excluding shareholders' funds) } \\
\text { required to be held in prime assets, like } \\
\text { cash or government securities. }\end{array}$ & \\
\hline $\operatorname{Jan} 90$ & $\begin{array}{l}\text { Distinction between trading and savings } \\
\text { banks removed. }\end{array}$ & \\
\hline
\end{tabular}

Feb 92 Further entry by foreign banks approved. 
Feb 92- Foreign banks given the choice of operatJune 94 ing as branch or locally incorporated subsidiary, but branches, unlike locally incorporated subsidiaries, not allowed to conduct retail banking business.

Sources: Battellino and Macmillan (1989); Gruen (1994); de Brouwer (1995).

\section{References}

Argy, F. (1996), 'The Integration of World Capital Markets: Some Economic and Social Implications', Economic Papers 15(2): 1-19.

Barro, R. (1996), 'Determinants of Economic Growth: A Cross-Country Empirical Study', National Bureau of Economic Research, Cambridge, Mass. (Working Paper No. 5698).

Battellino, R. \& N. Macmillan (1989), 'Changes in the Behaviour of Banks and their Implications for Financial Aggregates', RBA, Sydney (Research Discussion Paper No. 8904).

Blundell-Wignall, A., J. Fahrer \& A. Heath (1994), 'Major Influences on the Australian Dollar Exchange Rate', pp. $30-78$ in A. Blundell-Wignall (ed.), The Exchange Rate, International Trade and the Balance of Payments, RBA, Sydney.

Campbell, F. (1995), 'The Exchange Rate and the Reserve Bank's Role in the Foreign Exchange Market', pp. 39-54 in Seminar for Teachers, RBA, Sydney.

Carew, E. (1991), Fast Money 3: The Financial Markets in Australia, Allen \& Unwin, Sydney.

Cutler, D., J. Poterba \& L. Summers (1990a), 'Speculative Dynamics', National Bureau of Economic Research, Cambridge, Mass. (Working Paper No. 3242).

- (1990b), 'Speculative Dynamics and the Role of Feedback Traders', National Bureau of Economic Research, Cambridge, Mass. (Working Paper No. 3243).

Davidson, I., Okunev, J. and M. Tippett (1996), 'Some Further Evidence in Relation to ShortTermism of Stock Prices', School of Finance and Economics, University of Technology, Sydney (Working Paper No. 57).

Debelle, G. \& B. Preston (1995), 'Consumption, Investment and International Linkages', RBA, Sydney (Research Discussion Paper No. 9512).

de Brouwer, G. (1995), 'The Liberalisation and Integration of Domestic Financial Markets in Western Pacific Economies', RBA, Sydney (Research Discussion Paper No. 9506).

- (1996), 'Consumption and Liquidity Constraints in Australia and East Asia: Does Financial Integration Matter?', RBA, Sydney (Research Discussion Paper No. 9602).

Dwyer, J. \& D. Gruen (1995), 'Are Terms of Trade Rises Inflationary?', RBA, Sydney (Research Discussion Paper No. 9508).

Edey, M. \& K. Hviding (1995), 'An Assessment of Financial Reform in OECD Countries', OECD Economics Department, Paris (Working Paper No. 154).

Edey, M. \& B. Gray (1996), 'The Evolving Structure of the Australian Financial System', pp. 6-44 in M. Edey (ed.), The Future of the Financial System, RBA, Sydney.

Financial System Inquiry (1997), Final Report (S. Wallis, Chair), AGPS, Canberra.

Gelb, A., G. Jefferson \& I. Singh (1993), 'Can Communist Economies Transform Incrementally? China's Experience', School of Economics and Finance, University of Hong Kong (Discussion Paper No. 169). 
Goldsborough, D., S. Coorey, L. Dicks-Nireaux, B. Horvath, K. Kochhar, M. Mecagni, E. Offerdal \& J. Zhou (1996), 'Reinvigorating Growth in Developing Countries: Lessons from Adjustment Policies in Eight Economies', MMF, Washington DC (Occasional Paper No. 139).

Grenville, S. (1991), 'The Evolution of Deregulation', pp. 3-35 in I. Macfarlane (ed.), The Deregulation of Financial Intermediaries, RBA, Sydney.

- (1995), 'The Monetary Policy Transmission Process: What Do We Know?' (And What Don't We Know?)', Reserve Bank of Australia Bulletin, September: 19-33.

Gruen, D. (1994), 'Capital Flows, Monetary Exchange Rate Management: The Australian Experience', pp. 49-73 in Proceedings at the Eleventh Pacific Basin Central Bank Conference, Hong Kong, 31 October - 2 November 1994, Monetary and Exchange Rate Management with International Capital Mobility, Hong Kong Monetary Authority, Hong Kong.

— \& T. Kortian (1996), 'Why Does the Australian Dollar Move So Closely with the Terms of Trade?', RBA, Sydney (Research Discussion Paper No. 9601).

Gruen, D., J. Romalis \& N. Chandra (1997), 'The Lags of Monetary Policy', RBA, Sydney (Research Discussion Paper No. 9702).

Haggard, S., C. Lee \& S. Maxfield (eds) (1993), The Politics of Finance in Developing Countries, Comell University Press, Ithaca.

Harper, I. (1986), 'Why Financial Deregulation?', Australian Economic Review (1st Quarter): 37-49.

Isard, P. (1995), Exchange Rate Economics, Cambridge University Press, Cambridge.

Lowe, P. (1994), 'Financial Liberalisation: The Australian Experience', pp. 140-88 in R. Dombusch \& Y. Park (eds), Financial Opening: Policy Lessons for Korea, Korea Institute of Finance and the International Center for Economic Growth, Seoul.

(1995), 'The Link Between the Cash Rate and Market Interest Rates', RBA, Sydney (Research Discussion Paper No. 9504).

Milbourne, R. (1990), 'Money and Finance', pp. 222-81 in S. Grenville (ed.), The Australian MacroEconomy in the 1980s, RBA, Sydney.

Mills, K., S. Morling \& W. Tease (1994), The Influence of Financial Factors on Corporate Investment, RBA, Sydney (Research Discussion Paper No. 9402).

Reserve Bank of Australia (RBA) (1993), 'The Separation of Debt Management and Monetary Policy', Reserve Bank of Australia Bulletin, November: 1-5.

- (1996), Annual Report, Sydney.

Sachs, J., A. Tornell \& A. Velasco (1996), 'Financial Crises in Emerging Markets: the Lessons from 1995', National Bureau of Fconomic Research, Cambridge, Mass (Working Paper No. 5576).

'Tarditi, A. (1996), 'Australian Exchange Rates, Long Bond Yields and Inflationary Expectations', RBA, Sydney (Research Discussion Paper No. 9608).

This article is a revised version of a paper prepared for the Workshop on Financial Deregulation and International Capital Flows, 3-4 December 1996, organised by the National Centre for Development Studies at The Australian National University. The author is grateful for comments by Frank Campbell, Malcolm Edey, David Gruen and Tom Valentine. The views expressed in the article are the author's and do not necessarily represent those of the Reserve Bank of Australia. 